\title{
Biodesulfurization of Petroleum Distillates-Current Status, Opportunities and Future Challenges
}

\author{
Olawumi O. Sadare, Franklin Obazu and Michael Olawale Daramola * \\ Faculty of Engineering and the Built Environment, School of Chemical and Metallurgical Engineering, \\ University of the Witwatersrand, Johannesburg 2050, South Africa; 1592992@students.wits.ac.za (O.O.S.); \\ obazuf@gmail.com (F.O.) \\ * Correspondence: michael.daramola@wits.ac.za; Tel.: +27-117-177-536
}

Received: 15 October 2017; Accepted: 22 November 2017; Published: 25 November 2017

\begin{abstract}
Sulfur oxide $\left(\mathrm{SO}_{2}\right)$ and hydrogen sulfide $\left(\mathrm{H}_{2} \mathrm{~S}\right)$ are considered as one of the major air pollutants in the world today. In addition, high sulfur levels in petroleum distillates can promote the deactivation of catalysts through poisoning in fluidized catalytic cracking (FCC) during hydrocracking of the heavy distillates to lighter ones. The presence of high sulfur-containing compounds in the process streams could cause corrosion of piping and fittings and equipment, thereby damaging the pipelines and leading to air emissions of sulfur-containing compounds, which are undesirable for mankind and his environment. In many cases, a large quantity of $\mathrm{SO}_{x}$ is released into the atmosphere when petroleum distillates that contain substantial amount of sulphur-containing compounds are used as fuel and combust. In this article, a short overview of different desulfurization methods that are employed to remove sulfur from petroleum distillates is provided. In particular, the review concentrates on biodesulfurization technique. In addition, this article intends to provide its readers current status of biodesulfurization (BDS). It critically analyses the trend in the development of the technology to showcase its strength and weakness that could pave a way for future opportunities. Approaches that are suitable to remediate sulfur-contaminated environment are discussed as well. Lastly, speculations on future directions or opportunities that require exploration are provided as a way of provoking the thoughts of researchers in this field.
\end{abstract}

Keywords: biodesulfurization; sulfur; petroleum distillates; desulfurization; emissions; environment

\section{Introduction}

Energy production is among the most challenging concerns currently. Coal as a fossil fuel plays a significant part in the energy structure. Combustion of coal containing high sulfur results into emission of sulphur oxides leading to serious environmental issues, such as acid rain and severe air pollution [1]. The major problem in the refineries today is the refinement of the organic sulphur compounds from crude oil [2,3]. However, Pyrite has served as a model compound of inorganically bound sulfur in investigations of desulphurization. It is the main inorganic sulfur compound in high sulfur coal [4]. The world energy share from fossil fuels is still over $82 \%$, even though there is decrease in the fraction of energy that is obtained from fossil fuels currently [5]. Crude oil naturally occurs in the ground and they are majorly used as transportation fuels, such as diesel, gasoline, and jet fuels. The qualities of crude oil are greatly influenced by two properties namely; American Petroleum Institute (API) gravity and sulfur content and sulfur content [6]. Compounds of Sulfur exist in different forms that can be categorized into four groups namely: disulfides, mercaptans, thiophenes (THs), and sulfides [6]. There are different significant quantities of sulfur compounds in natural gas [7]. Sulfur compounds are unwanted in refining process owing to their tendency to catalyst deactivation during processing of crude oil. They also have poisoning potential and can lead to the corrosion of pumping equipment 
and pipelines $[6,8,9]$. Furthermore, they also serve as a source of air pollution in the environment [1]. The emission of sulfur dioxide is caused by naturally occurring sulfur compounds that are left behind in the fuels, which result into the emission of sulfur oxide gases. The reaction of water with these in the atmosphere form sulfates and acid rain leading to destruction of buildings. It also acidifies soil and eventually results in destruction of forests and hence the ecosystems [10]. The emission of sulfur has resulted into related health issues, like heart diseases, asthma, and respiratory illnesses. In addition, the presence of sulfur compounds in liquid fuels adversely affects vehicles. Sulfur levels in automotive fuels are responsible for lower efficiency of catalytic converters [6,11].

There are various techniques of reducing sulfur content in transportation fuel currently. These techniques have been investigated with different levels of achievement. The most commonly used method is hydrodesulfurization (HDS) [12]. HDS has succeeded in removing aromatic sulfur-containing compounds such as sulfones, thiolates, thiols and sulfoxides. Despite the extreme conditions (high temperatures and pressures) that are involved in HDS, some of the sulfur-containing compounds still remained, resulting in the reduction in quality of the fuel [13]. Therefore, the HDS method for deep desulphurization is expensive. In addition, some heterocyclic sulfur containing compounds, such as dibenzothiophene (DBT) and its alkyl substitutes, particularly 4 , 6-dimethyldibenzothiophene (4, 6-DMDBT) [14], are recalcitrant to HDS. Dimethyldibenzothiophene (DMDBT), being the least reactive of sulfur compounds also restricts HDS of petroleum distillates [6].

Other desulphurization techniques that are capable of producing ultra clean fuel are adsorptive desulfurization (AD), oxidation-extraction desulfurization (OEDS), desulfurization by oxidation (DO), and biodesulfurization (BDS). Desulpurization by adsorption is the process whereby an active adsorbent with a large surface area selectively removes the sulfur-containing compound. Oxidative desulphurization is a chemical reaction that involves the use of oxidizing agents such as; $\mathrm{H}_{2} \mathrm{O}_{2}, \mathrm{H}_{2} \mathrm{SO}_{4}$, etc. to oxidize sulfur containing compounds to sulfone. Due to the higher polarity of the sulfone compound, it can be easily extracted from the fuel. BDS has attracted a lot of attention recently owing to its green processing of fossil fuel. Conversely, the major hindrance to its use is slowness of the removal process. Recently, there are environmental regulations imposing a stringent limit for sulfur contents in transportation fuel. This is currently the strongest drive for the removal of sulfur in transportation fuels. In order to ensure the availability of energy at a lower cost by removing the sulfur from lower quality feed stocks there is urgent need for new efficient methods of desulphurization. In this article, different desulphurization techniques under investigation to reduce the sulfur-containing compounds in transportation fuels and bridge the gaps in these methods are reviewed.

\subsection{Effects of Sulfur}

Sulfur is toxic to humans, ecologically disastrous, and corrodes infrastructure. The existence of high sulfur-containing compounds in the process streams could have a lot of damaging effects, which is dangerous to health. This section presents and discusses the effects of sulfur with respect to mankind and its environment.

\subsubsection{Health}

Petroleum-based fuels, such as diesel and gasoline are used by internal combustion engines to power most automobiles. The emission of particulate matter (PM), nitrogen oxides $\left(\mathrm{NO}_{\mathrm{x}}\right)$, and carbon monoxide (CO), non-methane hydrocarbons, airborne toxins, and sulfur oxides $\left(\mathrm{SO}_{\mathrm{x}}\right)$ are usually caused by high temperature in cylinder of incomplete combustion of fuel. Some health issues and chronic diseases that are associated with exposure to these pollutants can eventually lead to early death [15].

Particulate matter (PM) is the most dangerous among the vehicle emissions. These categories of solid and liquid particles, lesser than 2.5 microns in aerodynamic diameter, $\left(\mathrm{PM}_{2.5}\right)$ can easily infiltrate into the lungs, stirring up inflammation and oxidative stress. In addition, the continuing exposure to $\mathrm{PM}_{2.5}$ causes a series of chronic illnesses in adults. These include respiratory infections, aggravation 
of existing asthma, lung cancer, ischemic heart disease, chronic bronchitis, as well as cerebrovascular disease [16]. Therefore, the reduction of sulfur-containing compounds from transportation fuel is essential in the petroleum industry. International Agency for Research on Cancer has confirmed that $\mathrm{PM}_{2.5}$ is a recognized carcinogen, which is mainly caused by diesel exhaust in transportation fuel [17]. Exposure to high concentrations of $\mathrm{PM}_{2.5}$ has been discovered to be connected to increase in hospital admissions that are related to infections of the respiratory organs [18], stroke, nonfatal heart attacks, and other acute outcomes [19]. Undesirable effects on reproduction, including reduced birth weight and increased death of children are also as a result of the emission of $\mathrm{PM}_{2.5}[20,21]$. New investigation into the impacts of black carbon on climate gives stronger proof that, if diesel particulate emissions can be controlled, it will reduce global warming [22]. Over the years, diesel black carbon has been extensively reduced in carbon dioxide equivalent emission by diesel engine polices in the state of California [23]. Therefore, the implementation of vehicle emission standards equivalent to Euro 6/VI for the international fleet would reduce the rate of premature mortality to between 120,000 and 280,000 in 2030 [17] at a worldwide standard.

\subsubsection{Environment and Climate}

The quality of the air is seriously affected by the pollution emitted by vehicle engines. There is a release of the sulfur oxides $\left(\mathrm{SO}_{\mathrm{x}}\right)$ and $\mathrm{NO}_{\mathrm{x}}$ into the atmosphere during the combustion of fuel. This could form sulfuric acid and nitric acid in the atmosphere when combined with water that lead to acid rain $[5,24,25]$. In addition, the release of sulfur-containing compounds in fuels into the environment leads to environmental concerns, such as water pollution (due to oil spillage) and global warming [26]. The vehicle manufacturers request for the removal of sulfur-containing compounds from petroleum, so as to reduce the global emissions of these compounds from vehicles [27]. These emission control devices are affected since sulfur is intensely adsorbed onto the metal catalysts, which inhibit the reaction and the adsorption of carbon monoxide, Nitrogen oxide $\left(\mathrm{NO}_{\mathrm{x}}\right)$, and hydrocarbons [28]. Furthermore, production of the oxy-acids of sulfur from combustion products causes the internal combustion engines parts to corrode [29]. Likewise, compounds of sulfur deactivate the catalysts that are used in hydrocarbon upgrading. In addition, they add to the formation of sticky deposits in petroleum products [30]. Therefore, sulfur compounds are unwanted in refining processes and their removal from petroleum distillates is important to the refineries and for human welfare.

\subsection{Effects of Sulphur-Containing Fuels on Economy}

Some of the economic impacts of $\mathrm{SO}_{\mathrm{x}}$ that are emitted due to the incomplete combustion of high-sulfur fuels have negative impacts on the economy of the nation. The acid rain as a result of this emission dissolves the calcium carbonate in monuments and buildings that are made with limestone and marble [31]. Sulfuric acid can cause huge economic losses owing to the occurrence of metal corrosion in machineries and vehicles in oil plants. Crude oils are refined and extracted by oil companies at varying levels. However, it is cheaper to refine crude that has lower sulfur content first, before refining crude with higher concentrations of sulfur. Since this is done the other way round, the oil reserves with lower sulfur contents would have been used up, leaving only high-sulfur concentrated crude oil to be used [32]. From estimation, the use of low sulfur fuels would be economically useful since it will prevent hospital emergencies and thousands of hospital admissions, lost working days, reduction of agricultural crop, and damage to commercial forest [33].

\subsection{Sulphur Content Regulations}

The reduction of sulphur content is anticipated to give room for the use of innovative emissions control methods that will significantly reduce PM emissions from diesel engines. The transformation started in the European Union and is now taking effect in North America. The need for greener fuels has made new emission standards to be implemented for automobiles in the United State of America since 2007 [34]. Nevertheless, there remain numerous reasons for reducing the sulfur content in 
transportation fuel. The substances emitted from by-products of combustion have also been connected to higher occurrences of bronchitis, lung and heart diseases and trigger asthma symptoms [35,36]. Therefore, in accordance with the international environmental law, sulfur compounds must be efficiently removed from fuels prior to release into the atmosphere $[37,38]$.

\section{Schedule of Sulfur Regulation for Countries}

It is also essential to remove sulfur content since it pollutes the advanced emission control systems [39]. The advanced emissions control systems have been aimed at furthering the reduction of $\mathrm{PM}$ and $\mathrm{NO}_{\mathrm{x}}$. Conversely, as the quantity of sulfur used-up is reduced, they are contaminated by the sulfur contents and become caked, resulting in poor performance until they become ineffective and there will be a necessity for total replacement of the control system. This makes the whole less economical causing several companies to choose less effective systems owing to the foreseen effects of sulfur pollutants in exhaust gases [38]. The allowable sulfur in diesel fuel was 50 ppm for highway vehicles since 2005, agreeing with the Euro IV emission regulation [40]. Although, Sweden since 1990 has offered low sulfur diesel, according to the Euro IV regulation, of which low sulfur diesel had infiltrated almost $100 \%$ of the transportation fuel market in 2000 . In addition, low aromatic diesel and zero sulfur have been obtainable since 2003 for use in extremely contaminated and confined regions [41]. In 2009, new Euro V standard was implemented for clean sulfur diesel (CSD) with a limit of 10 ppm for both highway and non-highway vehicles. Euro VI was the next standard implemented in 2013. This standard further restricts $\mathrm{NO}_{\mathbf{x}}$ and particulate matter missions, but is not affecting sulfur content directly [41].

The majority of the transportation fuel obtainable in the United States in 2006 attains <15 ppm CSD limits. Non-highway automobiles such as marine, trains, and off-road vehicles have met the requirement for $<500 \mathrm{ppm}$ clean transportation fuel limit before 2008 and they were mandatory to attain the CSD requirement in 2012 [42]. Furthermore, in 2003, United States Environmental Protection Agency (US EPA proposed a reduction of sulfur content in non-road diesel fuel from 3400 ppm to 500 ppm by the end of 2007, while the European Union enforced a policy for reduction of sulfur content in transportation fuel from 50 ppm to 10 ppm by 2009 [43-45]. Many countries such as, USA, Australia, New Zealand, Taiwan, Mexico, Singapore, Hong Kong, several Eastern and Central European countries, and other Asian countries have adopted a reduction in sulfur limits in transportation fuels according to the enforced policies from individual country [46-52].

In May 2015, the International Council on Clean Transportation (ICCT), in a G20 briefing paper reviews today's world-class emission standards, as shown in (Table 1) [53]. In addition, according to EPA assessments, implementing of the new fuel standards for diesel, the emission of soot or particulate matter were reduced by 110,000 tons a year, while $\mathrm{NO}_{\mathrm{x}}$ emissions were decreased by 2.6 million tons per year [49].

Some countries in Africa are already offering 50 ppm at filling stations. In 2009, Morocco launched 50 ppm diesel to fuel stations, likewise, several fuel stations stated offering 50 ppm by 2010 [54]. Furthermore, in order to reduce environmental pollution in Mauritius, 50 ppm diesel has been standardized across all of the filling stations since June 2012 [55]. Early in 2006, a report showed that the South African Department of Minerals and Energy first legislated 50 ppm and since has been generally available. Although an overview of $10 \mathrm{ppm}$ diesel to all filling stations was expected in December 2015. Sasol officially introduced 10 ppm diesel at few fuel stations in 2013. South African government launched South Africa's Clean Fuels 2 standard, early 2017. This will reduce the allowable sulphur content to 10ppm and will be available in all the filling stations all over the country [56]. 
Table 1. Summarizes today's world-class emission standards (with permission from ICCT).

\begin{tabular}{|c|c|}
\hline Policy Type & World-Class Emission Standard \\
\hline Green Freight & $\begin{array}{l}\text { Heavy-duty vehicles: Measures that promote } \\
\text { real-world, market-based performance } \\
\text { improvements tracked through standardized } \\
\text { and verifiable reporting mechanisms } \\
\text { (e.g., SmartWay in the U.S. and Canada). }\end{array}$ \\
\hline Clean, low-sulphur fuel & $\begin{array}{l}\text { - } 10 \text { to } 15 \text { parts per million (ppm) sulphur for } \\
\text { gasoline and diesel fuel plus Euro 6/VI, US Tier } \\
\text { 2/HD2010, or equivalent fuel specifications }\end{array}$ \\
\hline Fuel economy and $\mathrm{CO}_{2}$ standards & $\begin{array}{l}\text { - Passenger vehicles: } 95 \mathrm{~g} \mathrm{CO}_{2} / \mathrm{km} \text {, or measures } \\
\text { to cut new vehicle fuel consumption by half in } \\
2030 \text { from a } 2005 \text { baseline } \\
\text { - Heavy-duty vehicles: Measures to cut new } \\
\text { vehicle fuel consumption by } 35 \% \text { by } 2030 \text { from a } \\
2010 \text { baseline. }\end{array}$ \\
\hline Tailpipe emissions Standards & $\begin{array}{l}\text { - } \quad \text { Passenger vehicles: Euro } 6 \text { or US Tier } 2 * \\
\text { - } \quad \text { Heavy-duty vehicles: Euro VI or US HD2010* } \\
\text { In-use compliance programs (inspection and } \\
\text { maintenance, OBD, warranty and recall, etc.) }\end{array}$ \\
\hline
\end{tabular}

\footnotetext{
* Other equivalent standards include Japan PNLTES. Note that we expect US Tier 3 standards and California LEV III standards are expected. This is to establish a new level of world-class standards for passenger vehicles once they take effect in 2017 (Creative Commons Attribution-ShareAlike 3.0 Unported License).
}

\subsection{Existing Technologies for Desulphurization}

Desulphurization is the removal or reduction of $\mathrm{SO}_{2}$ level in distillates in order to meet the required standard. Numerous methods have been employed toward achieving this aim. Hydrodesulphurization (HDS) is one of the methods that are used to reduce the sulphur-containing compounds in transportation fuels [57]. Currently, most industries make use of HDS technique for sulphur removal from petroleum distillates. In the HDS technique, there is the generation of $\mathrm{H}_{2} \mathrm{~S}$ gas, when a metal catalyst is used along with hydrogen gas $\left(\mathrm{H}_{2}\right)$ at elevated temperature and pressure in order to remove sulphur from organo-sulfur compounds in transportation fuels [58]. Although, this method reduces the amount of sulphur in transportation fuels, however, there are numerous limitations that discourage its application. These include extreme operation conditions, such as high temperature and pressure [14,59]. In addition, this method of desulphurization has difficulty in removing recalcitrant heterocyclic sulphur compounds, such as dibenzothiophene (DBT) and its alkylated forms, such as 4-methyldibenzothiophene (4-DBT) and 4,6-dimethyldibenzothiophene (4,6-DBT) [58,60-64].

Currently, the strongest drive for the removal of sulphur in fuels is owing to the environmental guidelines, which are stringently imposing restrictions for sulphur levels in petroleum distillates. HDS technique is quite expensive because of the increase in the consumption of hydrogen gas, costly cobalt molybdenum catalyst, and severe operating conditions. Furthermore, it is difficult to lower the amount of sulphur in diesel to less than $15 \mathrm{ppm}$ with HDS technique. Therefore, new cost effective methods are sought throughout the world. Attention has been shifted to biodesulfurization (BDS) as an alternative method or a complementary process of removing sulphur containing compounds from fuels [65-70]. However, studies to improve the cost-effectiveness of the process are on-going. BDS technology is the future focus of most researchers throughout the world today because it employs microbes as bio-catalysts to remove sulphur from compounds that are recalcitrant to HDS [66]. Although, BDS 
has showed lower capital cost of desulphurization over the HDS process, however its low rate of conversion coupled with difficulties encountered in monitoring the operating conditions of bacteria growth and desulfurization capabilities hinder its commercial utilization [71]. Better understanding of the fundamentals that are involved with the microbes and improvement in biotechnological equipment are recently assisting in improving this challenge. This could pave a way toward the realization of viable goals of BDS, hence its choice in this article. Chemical structures of organic sulphur compounds existing in crude oil are presented in Figure 1.

$$
\begin{array}{ll}
\mathrm{R}-\mathrm{SH} & \mathrm{R}-\mathrm{S}-\mathrm{R}^{\prime} \\
\text { Thiols } & \text { Sulphides }
\end{array}
$$

\section{Sulphides}

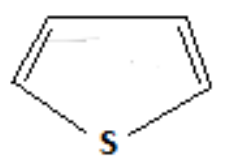

Thiophenes<smiles>c1ccc2sccc2c1</smiles>

Benzothiophenes<smiles>[R]SS[R]</smiles>

Disulphides<smiles>C1CCSC1</smiles>

Thiolanes<smiles>c1ccc2c(c1)sc1ccccc12</smiles>

Dibenzothiophenes

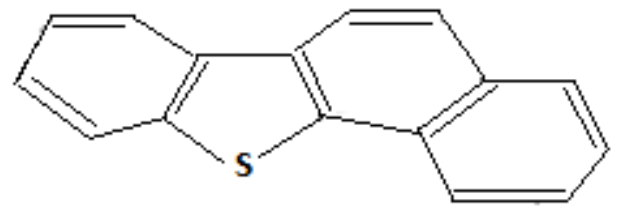

Benzonaphtothiophenes

Figure 1. Chemical structure of organic sulphur compounds present in crude oils. Adapted from [72].

\subsubsection{Hydrodesulfurization (HDS)}

Hydrodesulfurization (HDS) is a process that involves removal of sulfur compounds from the refined petroleum products with the use of a catalytic chemical process. HDS is a conventional way of reducing sulfur contents in fuel. This technology has been used since 1933, by which the organo-sulfur compounds are removed to lower levels by the use of metal catalyst [73]. Easy availability of hydrogen from catalytic reformers initially stimulated the interest in HDS [5,74]. Usually, the HDS process involves the conversion of a number of organo-sulfur compounds to $\mathrm{H}_{2} \mathrm{~S}$ and sulfur-free organic compounds. This can be done through catalytic treatment with hydrogen at elevated pressures, between 150 and $3000 \mathrm{psi}$, and elevated temperatures, between 290 and $455^{\circ} \mathrm{C}$ with the help of metal catalysts such as $\mathrm{CoMo} / \mathrm{Al}_{2} \mathrm{O}_{3}$ or $\mathrm{NiMo} / \mathrm{Al}_{2} \mathrm{O}_{3}$ [75-80]. This traditional HDS catalytic process for reducing sulfur content involves severe operation conditions, which makes the process expensive. In refineries, a modified version of the Claus process is used to convert the $\mathrm{H}_{2} \mathrm{~S}$ resulting from HDS process into elemental sulfur. [81]. The shortcomings of HDS process include: operation at elevated temperature and pressure, which eventually makes the process expensive and energy intensive. Also, some of the gas may not be reused again, which results into poor energy efficiency and the generation of environmental issues. The reactivity order of sulfur compounds from most to least reactive in HDS is as follows: thiophene $>$ alkylated thiophene $>$ BT $>$ alkylated BT $>$ DBT and MDBT $>4$ or 6-MDBT $>$ 4, 6-DMDBT [82]. Conclusively, the shortcomings of the HDS process has disadvantaged its practice, hence the reason for an alternative process. However, HDS still remains the artwork for desulfurization in petroleum refining industries. 


\subsubsection{Oxidative Desulfurization (ODS)}

Oxidative desulphurization involves the oxidation of the sulfur compounds to their corresponding sulfoxides (1-oxides) and sulfones (1,1-dioxides). This is contrary to the HDS method where sulfur compounds are reduced to form $\mathrm{H}_{2} \mathrm{~S}$. ODS for the reduction of sulphur is carried out at a reduced temperature $\left(\sim 50{ }^{\circ} \mathrm{C}\right)$ and pressure. This makes the process a promising technology [83]. In ODS, appropriate oxidants are used to oxidize heavy sulfides into thio sulfone forms by the addition of one or two oxygen atoms to the sulphur, without altering the carbon-sulphur bonds, resulting in the sulfone and sulfoxide, respectively [84]. There are differences in the polarities of sulfoxides and sulfones that are produced, and the hydrocarbons of similar structure. Sulfoxides and sulfones are more polar than hydrocarbon. This difference in polarity enables the removal of the sulfones by the selective solvent extraction of solid adsorption. Many reagents have been employed as oxidizing agents. These include hydrogen peroxide [85], organic hydroperoxides [86], and molecular oxygen. In order to accelerate the oxidation process, the use of catalyst has been introduced owing to the slow process of oxidation of sulphur compounds that are encountered in the absence of a catalyst. Various forms of catalysts have been investigated by different researchers [87-89]. Oxidative desulfurization provides many advantages when compared to the traditional HDS method of desulphurization. It can be carried out using mild operation conditions of temperature and pressure, and there is no need for expensive hydrogen. Conversely, the technique involves huge amounts of oxidizing agent and involves the separation procedure to recover the catalysts. In addition, the reaction suffers from low selectivity and activity, and therefore an extended reaction time is required.

\subsubsection{Adsorption Process}

This technique uses adsorbing agents (S-Zorb as they are called) having an affinity to adsorb sulfur containing compounds. S-Zorb sulfur reduction technique was created by ConocoPhillips to obtain ultra-low sulphur fuel. ConocoPhillips started operation in 2001 to market S-Zorb department at Borger refinery in Texas, USA due to a higher rate of production in thousands of barrels per day [90]. The adsorption could be of destructive type or what also could be termed as reactive adsorption, in which the adsorbed sulphur-containing compound is converted to a hydrocarbon after the stripping of its sulphur, which is left adsorbed on the adsorbing agent. On the other hand, adsorption could be of the non-destructive type (physical adsorption) i.e., one in which the chemical quality of the adsorbed sulphur containing species is preserved. In both cases, the adsorbing agent could be discarded or regenerated as convenient.

\subsubsection{Reactive Adsorption}

Reactive adsorption desulphurization involves the chemical reaction between the adsorbent and the sulfur compounds. The effectiveness of the method is dependent on the adsorbent properties that include: adsorption capacity, durability, selectivity for sulfur compounds, and adsorbent regeneration. The adsorbent can be regenerated after the adsorption process by eliminating the adsorbed sulfur compounds, subject to the method applied [91]. A study was conducted by Velu et al. [92] on adsorbents that can be regenerated to selectively remove sulfur from fuel for fuel cell application. Authors stated that desulfurization by adsorption could be a potential approach for many novel processes, such as IRVAD and Philips S-Zorb processes. A novel S-Zorb process for obtaining ultralow sulphur in transportation fuel was developed by Conoco Phillips Petroleum Co. in Houston, Texas, in the United State by reactive adsorption of sulphur heterocyclic compounds using a solid adsorbent at high temperatures and low hydrogen pressure. This was reported by Phillips Petroleum [93-95]. Reactive adsorption desulfurization utilizes the benefits of the adsorptive and HDS catalytic desulfurization, and therefore it is considered as an effective technique for deep desulfurization [96-99]. Transition metals supported on basic oxides can form an ideal adsorption system for this purpose [83]. Ni supported on $\mathrm{ZnO}$ is the most suggested adsorbent for this process, because $\mathrm{ZnO}$ is identified as 
a sulfur-acceptor that is released by sulfided $\mathrm{Ni}$ species for the period of regeneration, as well as hydrogenation co-catalyst of organo-sulfur compounds on the surface of Ni particles [100-102]

\subsubsection{Physical Adsorption}

Adsorptive desulfurization is the process whereby a solid adsorbent is used to remove a sulfur containing compound from fuel through physical reaction [91]. In this method, molecules are adsorbed intact; therefore the chemical characteristics of the sulfur containing compounds in gasoline and diesel are preserved [103]. Activated carbon and $\mathrm{Ni}-\mathrm{Al}_{2} \mathrm{O}_{3}$ have been investigated to be good adsorbents for removal thiophene, sulfide, and mercaptans, at moderate conditions of operation [2]. In this technique of desulphurization, the adsorption strength for various thiophene compounds are, 4, 6-DMDBT $>$ DBT $>$ BT $>2$-methyl thiophene > thiophene, which is the opposite for the HDS method. This is mainly because of the low sulfur uptake ability of the adsorbent material when the percentage of sulfur content in the oil fractions of interest is put into consideration. Another major setback of this adsorption method is the presence of competitive adsorption of aromatics and olefins, which results in a decrease in the sulfur uptake by the adsorbent [104-106]. Therefore, studies have suggested the use of pre-adsorbent for removing larger organo-sulfur molecules. This will enhance the uptake capacity of the adsorbent used. Two major challenges must be overcome in adsorption desulphurization. Firstly, high remunerable adsorbents must be developed with a high adsorption capacity for sulphur compounds. Secondly, adsorbents that selectively adsorb mainly aromatic sulphur compounds that are recalcitrant to HDS method must be developed over the other aromatic and olefinic compounds that are present in fuels from HDS units. Biodesulfurization is another newly employed method of removing sulphur-containing compounds from petroleum distillates.

\subsection{Biodesulfurization}

Biotechnology is the process whereby microorganisms are used to transform compounds for particular use. It is a vital instrument that is employed to develop new methods and to provide breakthroughs in numerous sectors, such as pharmaceutical, food, and agricultural industries [107]. Biodesulfurization makes use of a biological catalyst to remove organo-sulfur from petroleum distillates. BDS technique results in a low energy cost, minimal generation of unwanted products, and low emissions of sulfur containing compounds. This is owing to the ability of the biological catalysts to operate at an ambient temperature and pressure with great capacity to remove sulfur compounds [108-110].

Petroleum refining is a process that employs physicochemical processes. Nevertheless, owing to the characteristics of the biotechnological method, it has been used as an alternative, or rather to complement the advancement of petroleum development in refining processes. Studies have been carried out on different types of microorganisms at both batch and industrial scales for refining process application, such as biological demulsification, denitrogenation, demetallation, and enhancement of oil recovery by microorganism, conversion of heavy crude to light crude, and biological control of reservoir souring [109-111]. There are still many opportunities to be exploited in this field, even though various biotransformation processes have been described [112,113].

In BDS, bacteria removes organo-sulfur from petroleum distillates, leaving the carbon chain of the organo-sulfur compounds undamaged. Therefore BDS has often been used as an alternative method of desulfurization in place of HDS technique in refineries. The enzyme catalysed reaction method of removing sulphur from diesel fuel is now widely studied. There has been successful breakthrough in the use of biodesulfurization in the past 20 years. The first investigations were reported in the between 1950 's and 1960's [114,115]. BDS removes the recalcitrant sulphur compounds that HDS cannot remove at low operating conditions of temperature and pressure. Therefore, the choice of enzymes that can use DBT and other PAHs as sulfur sources in their growth metabolism and transform them into a harmless compound is essential [114]. In addition, studies have shown that the BDS technique is much cheaper than the HDS technique [116-118]. It has also been predicted that greenhouse gas emissions may be 
significantly reduced if the BDS process is used. [117]. Thiophenic compounds are used as carbon and sulphur sources by some of the isolated microorganisms, while some others used metabolized DBTs as a carbon source and they are converted after different steps of oxidation into a number of compounds that are soluble in water. However, the microbial growth and DBT oxidation rate could be significantly inhibited when the water-soluble end products accumulate [119].

\subsection{Recent Studies in BDS}

Several studies have been carried out on the use of microorganisms for the removal of sulphur from transportation fuel over the years. Refining processes by conventional methods have been carried out at an elevated temperature. Therefore, thermophilic BDS is required and could be easily incorporated into the refining process without cooling the stock to $30{ }^{\circ} \mathrm{C}$ [120]. Thermophilic BDS makes the development of crude oil BDS more practicable since it also lowers the viscosity of crude oil [121]. Currently a review paper was published by Soleimani et al. [122] on BDS of refractory organo-sulphur compounds in transportation fuels. This paper focuses on the outcomes of the latest investigation on BDS. A study on the enzymatic oxidation of DBT by horseradish peroxidase (HRP) step was evaluated by Madeira et al. [123]. The result showed that about $60 \%$ of DBT was transformed into dibenzothiophene sulfoxide (12\%) and 46\% dibenzothiophene sulfone at an optimum temperature, DBT concentration, molar ratio $\left(\mathrm{DBT}: \mathrm{H}_{2} \mathrm{O}_{2}\right)$, and reaction time of $45{ }^{\circ} \mathrm{C}, 0.267 \mathrm{Mm}$, 1:20, and $60 \mathrm{~min}$, respectively. Mohebali et al. conducted a BDS study on the removal of DBT from model oil, using both growth and resting stages of Gordonia lkanivorans (RIPI90A) bacterium, newly isolated [124]. The result showed that cells that were harvested at the late exponential stage had higher DBT desulfurizing capacities. Alves et al. [125] investigated on the enzymatic hydrolyzates of recycled paper sludge as suitable feedstock for BDS by Gordonia alkanivorans strain $1 \mathrm{~B}$. The result showed that, despite the increase in bacterial growth at non-dialyzed hydrolyzate, dialyzed-hydrolyzate obtained after enzymatic reaction displayed higher DBT desulfurization capacity. The maximum specific productivity of 2-hydroxybiphenyl (mol g/h) was achieved when $250 \mathrm{M}$ DBT was used up after four days for dialyzed hydrolyzate. DBT was noticed to be completely consumed when phosphate and ammonia were added. A further increase in the production of 2-hydroxybiphenyl by $14 \%$ was noticed. Caro et al. [126] studied the BDS capability of aerobic Rhodococcus erythropolis IGTS8 strain on DBT in oil-water emulsions. The result from the investigation showed that there was an increase in DBT diffusion into the aqueous phase when b-cyclodextrins was added, preventing HBP accumulation therefore improving the BDS yield. Furthermore, an increase in cell concentrations of biocatalyst decreased the rate of HBP production. This could be as a result of the limitation to mass transfer and inhibition effects. Chen et al. [127] investigated the desulphurization ability of bacterium Mycobacterium sp. ZD-19. The result showed that TH and BTH were completely removed in 10 and $42 \mathrm{~h}$, respectively. Also, about 100\% of DBT and 4, 6-DMDBT was removed in 50 and $56 \mathrm{~h}$ respectively. There was reduction in desulfurization efficiency when DBT and 4, 6-DMDBT were mixed together when compared to when they are desulfurized separately. This may be attributed to the existence of substrate competitive inhibition when DBT and 4,6-DMDBT are mixed. The desulfurization activities of five substrates were found to be in order of 4, 6-DMDBT $<$ DBT $<$ DPS $<$ BTH $<$ TH. Li et al. [128] studied the removal of DBT in tetradecane using a facultative thermophilic bacterium Mycobacterium goodii X7B. There was almost a $99 \%$ decrease in total sulfur level of DBT at $40{ }^{\circ} \mathrm{C}$ in $24 \mathrm{~h}$. About $59 \%$ of total sulphur was removed from Liaoning crude oil after $72 \mathrm{~h}$ treatment. Various studies of $\%$ sulphur removal from petroleum distillates by BDS techniques are summarized in Table 2 and Figure 2, at optimum temperatures and DBT concentrations using different microorganisms [124-139]. The microorganisms are abbreviated as follow; Gordonia alkanivorans RIPI90A (GAR 190A), Gordonia alkanivorans strain 1B (GAS 1B), Rhodococcus erythropolis IGTS8 (RE IGTS8), Mycobacterium sp. ZD-19 (M sp ZD-19), Mycobacterium goodii X7B (MG X7B), Caldariomyces fumago (CF), Bacillus subtilis WU-S2B (BS WU-F1), Mycobacterium phlei WU-F1 (MP WU-F1), Rhodococcus sp. strain P32C1 (RS P32C1), Rhodococcus erythropolis ATCC 53968 (RE ATCC 53968), Mycobacterium sp. X7B (M sp. X7B), Microbacterium strain 
ZD-M2 (MS ZD-M2), Pseudomonas stutzeri UP-1 (PS UP-1), Sphingomonas subarctica T7b (SS T7b), Bacterium, strain RIPI-22 (SS RIPI-22), Pseudomonas delafieldii R-8 (PD R-8).

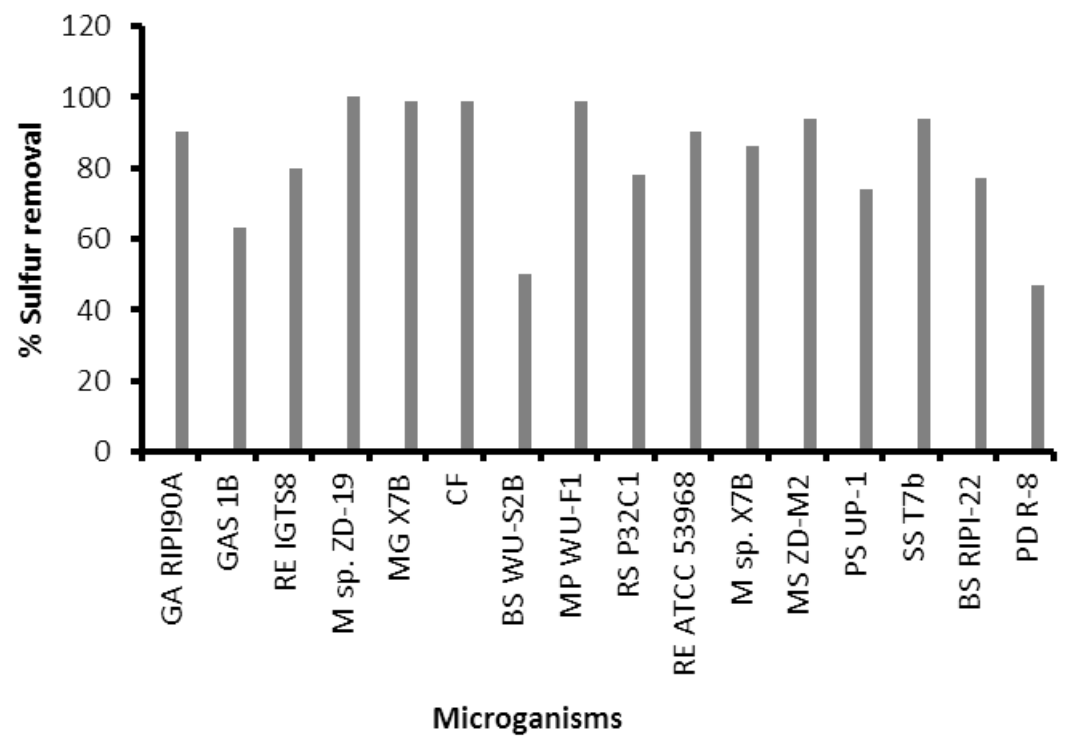

Figure 2. The percentage (\%) desulfurizing ability of various microorganisms.

Table 2. Optimized conditions of biodesulfurization process (Adapted from [6]).

\begin{tabular}{cccc}
\hline Bacteria & \multicolumn{2}{c}{ Optimum Conditions } & References \\
\hline GAR 190A & Sulfur Conc. $(\mathrm{ppm})$ & Temperatures $\left({ }^{\circ} \mathrm{C}\right)$ & {$[124]$} \\
GAS 1B & 100 & 30 & {$[125]$} \\
RE IGTS8 & 100 & 35 & {$[126]$} \\
M sp ZD-19 & 100 & 30 & {$[127]$} \\
MG X7B & 92 & 30 & {$[128]$} \\
CF & 200 & 40 & {$[129]$} \\
BS WU-S2B & 1600 & 25 & {$[130]$} \\
MP WU-F1 & 100 & 50 & {$[131]$} \\
RS P32C1 & 150 & & {$[132]$} \\
RE ATCC 53968 & 1000 & 30 & {$[133]$} \\
M sp. X7B & 184 & 30 & {$[134]$} \\
MS ZD-M2 & 535 & 45 & {$[135]$} \\
PS UP-1 & 36 & 30 & {$[136]$} \\
SS T7b & 500 & 31 & {$[137]$} \\
BS RIPI-22 & 280 & 27 & {$[138]$} \\
PD R-8 & 100 & 30 & {$[139]$} \\
\hline
\end{tabular}

\subsection{Sulphur Degradating/Removal Bacterial Strains}

Recently, many bacteria species, such as Arthrobacter, Brevibacterium, Pseudomonas, Gordona, and Rhodococcus strains, and other related bacteria species have been discovered to be able to transform DBT or to use it as their only sulfur source for their growth metabolism [140,141]. Rhodococcus strains are suitable for hydrocarbon metabolism. Many bacteria strains, such as Rhodococcus, Mycobacterium, and Pseudomonas species have transform organo-sulfur compounds in either of these three ways: one of three ways: $\mathrm{C}-\mathrm{S}$ bond cleavage (reductive), $\mathrm{C}-\mathrm{C}$ bond cleavage (oxidative), and $\mathrm{C}-\mathrm{S}$ bond cleavage (oxidative). The latter attacks only the sulfur atom that is leaving the carbon chain intact, therefore preserving the quality of the fuel. There are a lot of reports on the desulfurizing capability of Pseudomonas strains through DBT C-C bond cleavage pathway. These results have shown about $90 \%$ sulfur removal in $24 \mathrm{~h}$ by sulfur metabolising bacteria [142-144]. Dibenzothiophene has been investigated to be a model compound used in biodesulfurization of fuels. 
Dibenzothiophene (DBT) is the most widely used typical organo-sulphur compound in biodegradation and biodesulfurization studies [145-149]. Thus far, quite a few investigations have been carried out with DBT and alkyl-substituted DBTs using ring destructive DBT-degrading bacteria. DBT and its derivatives account for up to $70 \%$ of the sulphur content and they are the main organo-sulphur compounds in diesel fuel [150]. They are one of the compounds that are persistent and are mostly found in an oil contaminated environment [151,152]. DBT and its derivatives are refractory to the HDS method [153], surviving even to deep HDS treatment [154]. Moreover, DBT can be easily manipulated unlike other substances, because it is not mutagenic, neither is it dangerous to human health [155].

Use of Anaerobic and Aerobic Bacteria in Biodesulfurization

In anaerobic BDS, there is conversion of organic sulfur into hydrogen sulfide, which is later transformed into a sulfur atom. This process follows for the reductive desulfurization order and may be of use at the refinery since unwanted end products, such as coloured and gum-forming products, due to oxidation of hydrocarbons to undesired compounds, such as colored and gum-forming products, is residual [58]. Several anaerobic strains, such as Desulfovibrio desulfuricans, have demonstrated the ability to metabolize DBT during such a reductive desulfurization reaction. They also remove organic sulfur from petroleum feedstocks by reductive C-S bond cleavage (anaerobic BDS) [156]. However, it is difficult to maintain an anaerobic process [157].

Unlike anaerobic biodesulfurization, desulfurization by aerobic conditions occurs through oxidative pathways. These produce a water-soluble sulfate that is discarded alongside the unwanted aqueous phase. Desulfurization can occur in a different way depending on the substances present because the specificities of different strains differ for different sulfur compounds, and the pathway metabolism is not restricted to sulfur. This kind of desulfurization, however, comes with an associated carbon lost [158-160]. The sustainability of BDS depends on the selectivity of sulfur over carbon. It is important to harvest the microorganisms if the carbon metabolism is high, in order to retrieve some of the carbon lost during desulfurization. Tables 3 and 4 show the efficiency of aerobic cultures in real fuel desulfurization and desulfurization of alkylated dibenzothiophene with their end products respectively.

Table 3. Comparative characteristics of the efficiency of selected aerobic cultures in real fuel desulfurization.

\begin{tabular}{|c|c|c|c|}
\hline Culture & Oil Fraction & $\begin{array}{c}\text { Degree of } \\
\text { Desulphurization \% }\end{array}$ & Reference \\
\hline $\begin{array}{l}\text { Gordonia sp. P32C1 } \\
\quad \text { (resting cells) }\end{array}$ & $\begin{array}{l}\text { Light diesel fuel after hydrodesulfurization } \\
\text { (303 ppm) }\end{array}$ & 48.5 & [132] \\
\hline $\begin{array}{l}\text { Mycobacterium sp. X7B } \\
\text { (resting cells) }\end{array}$ & $\begin{array}{l}\text { Diesel fuel after hydrodesulfurization (535 } \\
\text { ppm) }\end{array}$ & 86 & [134] \\
\hline $\begin{array}{l}\text { Pseudomonas delafieldii } \\
\text { R_8 (growing cells) }\end{array}$ & $\begin{array}{l}\text { Diesel fuel after hydrodesulfurization (591 } \\
\text { ppm) }\end{array}$ & 47 & [139] \\
\hline $\begin{array}{l}\text { Gordonia sp. CYKS1 } \\
\text { (resting cells) }\end{array}$ & $\begin{array}{l}\text { Middle distillate unit feed (1500 ppm) } \\
\text { Light gasoil ( } 3000 \mathrm{ppm})\end{array}$ & $\begin{array}{l}70 \\
50\end{array}$ & [161] \\
\hline $\begin{array}{l}\text { Gordonia sp. SYKS1 } \\
\quad \text { (resting cells) }\end{array}$ & $\begin{array}{l}\text { Light gasoil ( } 3000 \mathrm{ppm}) \text { not subjected to } \\
\text { hydrodesulphurization } \\
\text { Middle distillate unit feed ( } 1500 \mathrm{ppm})\end{array}$ & $\begin{array}{l}35 \\
60\end{array}$ & [162] \\
\hline $\begin{array}{l}\text { Gordonia sp. SYKS1 } \\
\quad \text { (resting cells) }\end{array}$ & Diesel fuel (250 ppm) & 76 & [163] \\
\hline $\begin{array}{l}\text { Rhodococcus sp. ECRD_1 } \\
\text { (growing cells) }\end{array}$ & $\begin{array}{l}\text { Medium fraction of light gasoil after } \\
\text { catalytic cracking ( } 669 \mathrm{ppm})\end{array}$ & 92 & [164] \\
\hline $\begin{array}{l}\text { Rhodococcus erythropolis } \\
\text { I_19 (resting cells) }\end{array}$ & $\begin{array}{l}\text { Medium distillate after } \\
\text { hydrodesulfurization (1850 ppm) }\end{array}$ & 67 & [165] \\
\hline $\begin{array}{c}\text { Mycobacterium phlei } \\
\text { WU_0103 (growing cells) }\end{array}$ & $\begin{array}{l}\text { Straight-run light gasoil diluted } 12 \text { times } \\
(1000 \mathrm{ppm})\end{array}$ & 52 & [166] \\
\hline $\begin{array}{l}\text { Pseudomonas delafieldii } \\
\text { R_8 (resting cells) }\end{array}$ & $\begin{array}{l}\text { Diesel fuel after hydrodesulfurization (591 } \\
\text { ppm) }\end{array}$ & 90.5 & [167] \\
\hline
\end{tabular}


Table 4. Alkylated DBTs (Cx-DBT) desulfurization by some bacterial strains and their end products.

\begin{tabular}{|c|c|c|c|}
\hline Bacterium & Sulphur Substrate(s) & End Product(s) & References \\
\hline $\begin{array}{l}\text { Rhodococcus erythropolis } \\
\text { KA2-5-1 }\end{array}$ & Alkylated DBTs (C2-DBTs and C3-DBTs) & Corresponding hydroxylated Biphenyls & [168] \\
\hline $\begin{array}{l}\text { Rhodococcus erythropolis } \\
\text { H-2 }\end{array}$ & $\begin{array}{l}\text { 2,8-DMDBT, 4,6-DMDBT } \\
\text { 3,4-Benzo-DBT }\end{array}$ & $\begin{array}{l}\text { Corresponding hydroxylated biphenyl } \\
\text { a-Hydroxy-b-phenylnaphthalene }\end{array}$ & [169] \\
\hline Bacterial strain RIPI-S81 & $\begin{array}{c}\text { 4-MDBT } \\
\text { 4,6-DMDBT }\end{array}$ & $\begin{array}{l}\text { 2-Hydroxy-3-methylbiphenyl, } \\
\text { 2-hydroxy-3-methylbiphenyl } \\
\text { 2-Hydroxydimethylbiphenyl }\end{array}$ & [170] \\
\hline Mycobacterium sp. G3 & $\begin{array}{c}\text { 4,6-Dibutyl DBT, 4,6-dipentyl DBT; } \\
\text { 4,6-DMDBT, 4,6-DEDBT }\end{array}$ & C-S bond cleavage products & [171] \\
\hline Paenibacillus sp. A11-2 & $\begin{array}{l}\text { Methyl, ethyl, dimethyl, trimethyl and } \\
\text { propyl DBTs }\end{array}$ & $\begin{array}{l}\text { Corresponding hydroxylated } \\
\text { Biphenyls }\end{array}$ & $\begin{array}{l}120] \\
{[141]}\end{array}$ \\
\hline Rhodococcus sp. ECRD-1 & 4,6-DEDBT & Hydroxydimethylbiphenyl & [172] \\
\hline
\end{tabular}

\section{Issues in Biodesulfurization for Its Industrial Application}

Over the years, there have been issues on the industrial application of BDS, although it serves as a complementary process to hydrodesulfurization. This is due to several challenges that are faced at both upstream and downsteam processes. One of the major problems hindering the useful application of BDS in the industries is the high cost of growing bacteria in a culture medium. In view of this, use of carbon sources that are obtained from industrial agricultural products can serve as alternatives so as to reduce capital expenses [173,174]. Alves et al. [175] investigated a fructose-rich carbon source using G. alkanivorans strain 1B to desulfurize sulfur heterocyclic compound in transportation fuel. The authors reported a higher desulfurizing capability of this strain on BT and DBT when compared with Rhodococcus erythropolis. The cost of microorganism can be another challenge for application of BDS in the industry. In other to overcome this challenge, the immobilization of cell has been suggested to be a feasible solution [176]. The reported technique by Rosenberg et al. [174] was adopted to study the affinity of Pseudomonas species towards some hydrocarbons. The result obtained indicated that an increase in adsorption of bacteria onto the hydrocarbon increases the percentage organic phase [176]. Cell immobilization helps in the recovery of biocatalysts after treatment of microorganisms. The partial challenge that is encountered by BDS through the rate of transfer of sulphur heterocyclic compounds from oil phase into the microbial cell is also hindered during BDS, which affects the full application of BDS at industrial scale. Goubin et al. [177] assembled $\gamma-\mathrm{Al}_{2} \mathrm{O}_{3}$ nanosorbents on Pseudomonas delafieldii R-8 strain. It was shown from the result that adsorption rate was higher when compared to the rate of BDS. The assembly of the nano-adsorbent enhanced the transfer of the organo-sulfur (DBT) from the oil phase to the surface of the bacteria.

\section{Conclusions and Future Outlook}

This review has highlighted that sulphur has severe impacts on human life and its environment. In this piece, a wide range of conventional and non-conventional methods for the desulfurization of sulphur-containing petroleum distillates have been presented. Regarding BDS, an in-depth understanding of how bacteria metabolize sulphur heterocycles requires extensive studies. Based on this review, the following suggestions need to be considered in the development of a new BDS process.

(i) In depth investigation into the understanding of the various microbial pathways that are involved in BDS is required towards the optimization and scale-up studies of the process.

(ii) In addition, studies that will explore the combination of BDS with existing methods could be instrumental to achieving a higher reduction in sulphur-containing compounds in the petroleum distillates.

(iii) At the same time, the development of new strains or the modification of sulphur degrading strains via recombinant DNA technology or genetic engineering could be essential to enhancing the degrading performance of the existing bacteria. 
Author Contributions: Olawumi O. Sadare, Franklin Obasu and Michael Olawale Daramola conceived the idea and wrote the paper.

Conflicts of Interest: The authors declare no conflict of interest.

\section{References}

1. Kan, H.; Wong, C.M.; Vichit-Vadakan, N.; Qian, Z. The PAPA project teams short term association between sulphur dioxide and daily mortality: The public health and air pollution in Asia (PAPA) study. Environ. Res. 2010, 110, 258-264. [CrossRef] [PubMed]

2. Babich, I.V.; Moulijn, J.A. Science and technology of novel processes for deep desulfurization of oil refinery streams: A review. Fuel 2003, 82, 607-631. [CrossRef]

3. Bergh, C. Energy Efficiency in the South African Crude Oil Refining Industry: Drivers, Barriers and Opportunities. Master's Thesis, University of Cape Town, Cape Town, South Africa, 29 May 2012.

4. Weerasekara, N.S.; García Frutos, F.J.; Cara, J.; Lockwood, F.C. Mathematical modelling of demineralisation of high sulphur coal by bioleaching. Miner. Eng. 2008, 21, 234-240. [CrossRef]

5. Duissenov, D. Production and Processing of Sour Crude and Natural Gas-Challenges due to Increasing Stringent Regulations; Norwegian University of Science and Technology Faculty of Engineering Science and Technology Department of Petroleum Engineering and Applied Geophysics: Trondheim, Norway, 2013; p. 1.

6. Srivastava, V.C. An evaluation of desulfurization technologies for sulphur removal from liquid fuels. RSC Adv. 2012, 2, 759-783. [CrossRef]

7. Chambers, L.; Duffy, M.L. Determination of Total and Speciated Sulfur Content in Petrochemical Samples Using a Pulsed Flame Photometric Detector. J. Chromatogr. Sci. 2003, 41, 528-534. [CrossRef]

8. Dunleavy, J.K. Sulphur as a Catalyst Poison. Platin. Met. Rev. 2006, 50, 110. [CrossRef]

9. Ma, Z.; Wei, L.; Zhou, W.; Jia, L.; Hou, B.; Li, D.; Zhao, Y. Overview of catalyst application in petroleum refinery for biomass catalytic pyrolysis and bio-oil upgrading. RSC Adv. 2015, 5, 88287-88297. [CrossRef]

10. Fang, W.L. Inventory of U.S Greenhouse Gas Emission and Sinks 1990-2003; Clear Air Market Division, United States Environmental Protection Agency: Washington, DC, USA, 2004.

11. Policy Briefs on Global Atmospheric Pollution Forum. Available online: https://www.sei-international.org/ gapforum/policy/effectshumanhealth.php (accessed on 4 October 2016).

12. Javadli, R.; de Klerk, A. Desulfurization of heavy oil. Appl. Petrochem. Res. 2012, 1-4, 3-19. [CrossRef]

13. Ma, X.; Sakanishi, K.; Mochida, I. Three-stage deep hydrodesulfurization and decolorization of diesel fuel with CoMo and NiMo catalysts at relatively low pressure. Fuel 1994, 73, 1667-1671. [CrossRef]

14. Monticello, D.J. Riding the fossil fuel biodesulfurization wave. ChemTech 1998, 28, 38-45.

15. Sharaf, J. Exhaust Emissions and Its Control Technology for an Internal Combustion Engine. Int. J. Eng. Res. Appl. 2013, 3, 947-960.

16. Chambliss, S.; Josh Miller, J.; Façanha, C.; Minjares, R.; Blumberg, K. The Impact of Stringent Fuel and Vehicle Standards on Premature mortality and Emissions; ICCT'S Global Transportation Health and Climate Roadmap Series; International Council on Clean Transportation: Washington, DC, USA, 2013; pp. 1-89.

17. McClellan, R.O.; Hesterberg, T.W.; Wall, J.C. Evaluation of carcinogenic hazard of diesel engine exhaust needs to consider revolutionary changes in diesel technology. Regul. Toxicol. Pharmacol. 2012, 63, $225-258$. [CrossRef] [PubMed]

18. Yu, H.; Chien, L. Short-term population-based non-linear concentration-response associations between fine particulate matter and respiratory diseases in Taipei (Taiwan): A spatiotemporal analysis. J. Expo. Sci. Environ. Epidemiol. 2016, 26, 197-206. [CrossRef] [PubMed]

19. Lisabeth, L.D.; Escobar, J.D.; Dvonch, J.T.; Sanchez, B.N.; Majersik, J.J.; Brown, D.L.; Smith, M.A.; Morgenstern, L.B. Ambient air pollution and risk of ischemic stroke and TIA. Ann. Neurol. 2008, 64, 53-59. [CrossRef] [PubMed]

20. Woodruff, T.J.; Darrow, L.A.; Parker, J.D. Air pollution and postneonatal infant mortality in the United States, 1999-2002. Environ. Health Perspect. 2008, 116, 110-115. [CrossRef] [PubMed]

21. Geer, L.A.; Weedon, J.M.L. Ambient air pollution and term birth weight in Texas from 1998 to 2004. J. Air Waste Manag. Assoc. 2012, 62, 1285-1295. [CrossRef] [PubMed]

22. Jacobson, M.Z. Control of fossil fuel particulate black carbon and organic matter, possibly the most effective method of slowing global warming. J. Geophys. Res. 2002, 107. [CrossRef] 
23. Air Resource Board. Black Carbon Emissions Reduced by ARB Regulations; Califonia Environmental Protection Agency: Sacramento, CA, USA, 2013; pp. 1-89.

24. Koch, T.A.; Krause, K.R.; Manzer, L.E.; Mehdizadeh, M.; Odom, J.M.; Sengupta, S.K. Environmental challenges facing the chemical-industry. New J. Chem. 1996, 20, 163-173.

25. Whitehurst, D.D.; Isoda, I.; Mochida, I. Present state of art and future challenges in hydrodesulfurization of polyaromatic sulfur compounds. Adv. Catal. 1998, 42, 345-357.

26. Shiraishi, Y.; Hirai, T.; Komasawa, I. Deep Desulfurization Process for Light Oils by Photochemical Reaction in an Organic Two-Phase Liquid-Liquid Extraction System. Ind. Eng. Chem. Res. 1998, 37, 203-211. [CrossRef]

27. Parkinson, G. Refiners crack down on sulphur. Chem. Eng. 2000, 107, 45-48.

28. USEPA. Available online: http://www.epa.Gov/sbrefaldocuments/pnl13f.Pdf (accessed on 25 October 2016).

29. Collins, F.M.; Lucy, A.R.; Sharp, C.J. Oxidative desulfurization of oils via hydrogen peroxide and heteropolyanion catalysis. J. Mol. Catal. A Chem. 1997, 117, 397-403. [CrossRef]

30. Tam, P.S.; Kittrell, J.R.; Eldridge, J.W. Desulfurization of fuel oil by oxidation and extraction. 1. Enhancement of extraction oil yield. Ind. Eng. Chem. Res. 1990, 29, 321-324. [CrossRef]

31. Bravo, A.H.; Soto, A.R.; Sosa, E.R.; Sánchez, A.P.; Alarcón, J.A.L.; Kahl, J.J.; Ruíz, B.J. Effect of acid rain on building material of the El Tajín archaeological zone in Veracruz, Mexico. Environ. Pollut. 2006, 144, 655-660. [CrossRef] [PubMed]

32. Jones, J.A. Deep Desulfurization of Diesel Fuel Using a Single Phase Photochemical Microreactor. Master's Thesis, Oregon State University, Corvallis, OR, USA, 25 October 2010.

33. UNEPA. Report of the Partnership for Clean Fuels and Vehicles (PCFV), pp. 1-14. Available online: http:// www.staging.unep.org/transport/pcfv/PDF/SulphurReport-Brochure.pdf (accessed on 23 November 2017).

34. Omidvarborna, H.; Kumar, A.; Kim, D.S. Characterization of particulate matter emitted from transit buses fueled with B20 in idle modes. J. Environ. Chem. Eng. 2014, 2, 2335-2342. [CrossRef]

35. Cackette, T. Importance of Reducing Emissions from Heavy-Duty Vehicles; California Air Resources Board: Sacramento, CA, USA, 1999; p. 15.

36. Gauderman, W.J.; Gilliland, G.F.; Vora, H.; Avol, E.; Stram, D.; McConnell, R.; Thomas, D.; Lurmann, F.; Margolis, H.G.; Rappaport, E.B. Association between Air Pollution and Lung Function Growth in Southern California Children: Results from a second cohort. Am. J. Respir. Crit. Care Med. 2000, 166, 76-84. [CrossRef] [PubMed]

37. Sayyadnejad, M.A.; Ghaffarian, H.R.; Saeidi, M. Removal of hydrogen sulfide by zinc oxide nanoparticles in drilling fluid. Int. J. Environ. Sci. Technol. 2008, 5, 565-569. [CrossRef]

38. Sekhavatjou, M.S.; Moradi, R.; Alhashemi, A.H.; Hejabi, T. A New Method for Sulphur Components Removal from Sour gas through Application of Zinc and Iron Oxides Nanoparticles. Int. J. Environ. Res. 2014, 8, 273-278.

39. United States Environmental Protection Agency (UEPA) 2016. Available online: https: / /www.epa.gov/ gasoline-standards / gasoline-sulfur (accessed on 23 November 2017).

40. Shell Global. Available online: http://www.shell.com/.../sg-en/shell_for_motorists/fuels/diesel/ulsd_ faqs_0914.html?LN=/leftnavs/zzz_lhn4_3_4.html (accessed on 10 October 2016).

41. Lloyd, A.C.; Cackette, T.A. Diesel Engines: Environmental Impact and Control. J. Air Waste Manag. Assoc. 2001, 51, 809-847. [CrossRef] [PubMed]

42. Barrett, S.R.; Yim, S.H.; Gilmore, C.K.; Murray, L.T.; Kuhn, S.R.; Tai, A.P.; Yantosca, R.M.; Byun, D.W.; Ngan, F.; Li, X.; et al. Public Health, Climate, and Economic Impacts of Desulfurizing Jet Fuel. Environ. Sci. Technol. 2012, 46, 4275-4282. [CrossRef] [PubMed]

43. Song, C. An overview of new approaches to deep desulfurization for ultra-clean gasoline, diesel fuel and jet fuel. Catal. Today 2003, 86, 211-263. [CrossRef]

44. Marcelis, C. Anaerobic Biodesulfurization of Thiophenes. Ph.D. Thesis, Wageningen University, Wageningen, The Netherlands, 2002.

45. Bailey, D.; Plenys, T.; Solomon, G.M.; Campbell, T.R.; Feuer, G.R.; Masters, J.; Tonkonogy, B. Harboring Pollution Strategies to Clean Up U.S. Ports; Natural Resources Defense Council: New York, NY, USA, 2004; pp. 1-97. 
46. Kilbane, J.J. Microbial biocatalyst development to upgrade fossil fuels. Curr. Opin. Biotechnol. 2006, 17, 305-314. [CrossRef] [PubMed]

47. The Info List-Ultra-Low Sulfur Diesel. Available online: http://www.theinfolist.com/php/SummaryGet. php?FindGo=Ultra-Low\%20Sulfur\%20Diesel (accessed on 21 November 2016).

48. Banerjee, S. The European Fuels Conference. Overview of the Asian Fuel Market. Available online: http:/ / www.efoa.eu/documents / document/20110328145537-2011-03-09_overview_of_the_asian_ fuel_ether_market_and_opportunities_for_europe.pdf (accessed on 23 November 2017).

49. Overview of Air Pollution from Transportation. Available online: https://www.epa.gov/air-pollutiontransportation/learn-about-air-pollution-transportation (accessed on 2 November 2016).

50. Fuel Quality in Australia, 2001. Available online: http://www.environment.gov.au/topics/environmentprotection/fuel-quality/standards / diesel (accessed on 21 November 2016).

51. Diesel Fuel Specifications-Korea. Diesel Fuel EN 590. Available online: https:/ / en590.wordpress.com/ (accessed on 21 November 2016).

52. Zietsman, J.; Farzaneh, M.; Storey, J.M.E.; Villa, J.; Ojah, M.; Lee, D.W.; Bella, P. Emissions of Mexican-Domiciled Heavy-Duty Diesel Trucks Using Alternative Fuels; Texas Transportation Institute: College Station, TX, USA, 2007; pp. 4-70.

53. Kodjak, D. Policies to Reduce Fuel Consumption, Air Pollution, and Carbon Emissions from Vehicles in G20 Nations; The International Council on Clean Transportation: Washington, DC, USA, 2015; pp. 1-22.

54. AECC Newsletter, 2015. Available online: http:/ /www.aecc.eu/en/content/pdf/AECC\%20Newsletter\% 20May-June\%202010.pdf (accessed on 22 November 2016).

55. United Nation Environment Programme, 2012. Available online: http:/ / www.unep.org/transport/pcfv / meetings/mauritius50ppm.asp (accessed on 2 November 2016).

56. Industry News. Available online: http://www.iol.co.za/motoring/industry-news/sasol-launches-10ppmclean-diesel-1.1611081\#.UpNbXsQW1KJ (accessed on 2 November 2016).

57. Shafi, R.; Hutchings, G.J. Hydrodesulfurization of hindered dibenzothiophenes: An overview. Catal. Today 2000, 59, 423-442. [CrossRef]

58. Startsev, A.N. The Reaction Mechanisms of $\mathrm{H}_{2} \mathrm{~S}$ Decomposition into Hydrogen and Sulfur: Application of Classical and Biological Thermodynamics. J. Thermodyn. Catal. 2017, 8, 2-8.

59. Bachmann, R.T.; Johnson, A.C.; Edyvean, R.G.J. Biotechnology in the petroleum industry: An overview. Int. Biodeterior. Biodegrad. 2014, 86, 225-237.

60. Kabe, T.; Ishihara, A.; Tajima, H. Hydrodesulfurization of sulfur-containing polyaromatic compounds in light oil. Ind. Eng. Chem. Res. 1992, 31, 1577-1580. [CrossRef]

61. Abin-Fuentes, A.; Leung, J.C.; El-Said Mohamed, M.; Wang, D.I.C.; Prather, K.L.J. Rate-limiting step analysis of the microbial desulfurization of dibenzothiophene in a model oil system. Biotechnol. Bioeng. 2014, 111, 876-884. [CrossRef] [PubMed]

62. Zhang, S.; Chen, H.; Li, W. Kinetic analysis of biodesulfurization of model oil containing multiple alkyl dibenzothiophenes. Appl. Microbiol. Biotechnol. 2013, 97, 2193-2200. [CrossRef] [PubMed]

63. Tanaka, H.; Boulinguiez, M.; Vrinat, M. Hydrodesulfurization of thiophene, dibenzothiophene and gasoil on various $\mathrm{Co}-\mathrm{Mo} / \mathrm{TiO}_{2}-\mathrm{Al}_{2} \mathrm{O}_{3}$ catalysis. Catal. Today 1996, 29, 209-213. [CrossRef]

64. Zeelani, G.G.; Dr., Sundar Lal Pal, S.L. A Review on Desulfurization Techniques of Liquid Fuels. Int. J. Sci. Res. 2016, 5, 2413-2419.

65. Shong, R.G. Bioprocessing of Crude Oils. Texaco Exploration \& Producing Technology Department: Houston, Texas, 77042. Available online: https://web.anl.gov/PCS/acsfuel/preprint\%20archive/Files/Volumes / Vol44-1.pdf (accessed on 23 November 2017).

66. Boniek, D.; Figueiredo, D.; Batista dos Santos, A.F.; De Resende Stoianoff, M.A. Biodesulfurization: A mini review about the immediate search for the future technology. Clean Technol. Environ. Policy 2015, 17, $29-37$. [CrossRef]

67. Montiel, C.; Quintero, R.; Aburto, J. Petroleum biotechnology: Technology trends from the future. Afr. J. Biotechnol. 2009, 8, 2653-2666.

68. Zhang, Y.; Wang, D.; Zhang, R.; Zhao, J.; Zheng, Y. ZSM-5-Ln(Pc)2 catalyzed oxygen oxidation of thiophene. Catal. Commun. 2012, 29, 21-23. [CrossRef]

69. Wang, W.; Wang, S.; Liu, H.; Wang, Z. Desulfurization of gasoline by a new method of electrochemical catalytic oxidation. Fuel 2007, 86, 2747-2753. [CrossRef] 
70. Zhao, H.; Xia, S.; Ma, P. Use of ionic liquids as "green" solvents for extractions. Chem. Technol. Biotechnol. 2005, 80, 1089-1096. [CrossRef]

71. Mohamed, M.E.; Al-Yacoub, Z.H.; Vedakumar, V.J. Biocatalytic desulfurization of thiophenic compounds and crude oil by newly isolated bacteria. Front. Microbiol. 2015, 6. [CrossRef] [PubMed]

72. Hosseini, H.; Hamidi, A. Sulfur Removal of Crude Oil by Ultrasound Assisted Oxidative Method. In Proceedings of the International Conference on Biological, Civil and Environmental Engineering (BCEE-2014), Dubai, United Arab Emirates, 17-18 March 2014.

73. Bose, D. Parameters for a Hydro desulfurization (HDS) Unit for Petroleum Naphtha at 3500 Barrels per Day. World Sci. News 2015, 9, 99-111.

74. Gary, J.H.; Handwerk, G.E. Petroleum Refining Technology and Economics, 2nd ed.; Marcel Dekker, Inc.: New York, NY, USA, 1984.

75. Medici, L.; Prins, R. The Influence of Chelating Ligands on the Sulfidation of Ni and Mo in $\mathrm{NiMo} / \mathrm{SiO}_{2}$ Hydrotreating Catalysts. J. Catal. 1996, 163, 38-49. [CrossRef]

76. Hensen, E.J.M.; de Beer, V.H.J.; Van Veen, J.A.R.; van Santen, R.A. On the sulfur tolerance of supported Ni (Co)Mo sulfide hydrotreating catalysts. J. Catal. 2003, 215, 353-357. [CrossRef]

77. Rob van Veen, J.A.R.; Gerkema, E.; van der Kraan, A.M.; Hendriks, P.A.J.M.; Beens, H. A 57Co Mossbauer emission spectrometric study of some supported CoMo hydrodesulfurization catalysts. J. Catal. 1992, 133, 112-123. [CrossRef]

78. Ohta, Y.; Shimizu, T.; Honma, T.; Yamada, M. Effect of chelating agents on HDS and aromatic hydrogenation over CoMo-and $\mathrm{NiW} / \mathrm{Al}_{2} \mathrm{O}_{3}$. Stud. Surf. Sci. Catal. 1999, 127, 161-168.

79. Cattaneo, R.; Rota, F.; Prins, R. An XAFS Study of the Different Influence of Chelating Ligands on the HDN and HDS of $\gamma-\mathrm{Al}_{2} \mathrm{O}_{3}$-Supported NiMo Catalysts. J. Catal. 2001, 199, 318-327. [CrossRef]

80. Bouwens, S.M.A.M.; van Zon, F.B.M.; van Dijk, M.P.; van der Kraan, A.M.; de Beer, V.H.J.; van Veen, J.A.R.; Koningsberger, D.C. On the structural differences between alumina-supported CoMoS type I and alumina-, silica-, and carbon-supported CoMoS type II phases studied by XAFS, MES, and XPS. J. Catal. 1994, 146, 375-393. [CrossRef]

81. Shen, Y.; Liu, X.; Sun, T.; Jia, J. Recent advances of sodium boronhydride reduction in coal water slurry desulfurization: Integration of chemical and electrochemical reduction. RSC Adv. 2012, 2, 8867-8882. [CrossRef]

82. Gupta, N.; Roychoudhury, P.K.; Deb, J.K. Biotechnology of desulfurization of diesel: Prospects and challenges. Appl. Microbiol. Biotechnol. 2005, 66, 356-366. [CrossRef] [PubMed]

83. Zhang, G.; Yu, F.; Wang, R. Research advances in oxidative desulfurization technologies for the production of low sulfur fuel oils. Pet. Coal 2009, 51, 196-207.

84. Paniv, P.M.; Pysh'ev, S.V.; Gaivanovich, V.I.; Lazorko, O.I. Current Problems, Nontraditional Technologies, Noncatalytic oxidation desulfurization of the kerosene cut. Chem. Technol. Fuels Oils 2006, 42, 159-166. [CrossRef]

85. Hirai, T.; Ogawa, K.; Komasawa, I. Desulfurization process for dibenzothiophenes from light oil by photochemical reaction and liquid-liquid extraction. Ind. Eng. Chem. Res. 1996, 35, 586-589. [CrossRef]

86. Kocal, J.A.; Branvold, T.A. Removal of Sulfur-Containing Compounds from Liquid Hydrocarbon Streams. U.S. Patent 6368495, 9 April 2002.

87. Chica, A.; Corma, A.; Dómine, M.E. Catalytic oxidative desulfurization (ODS) of diesel fuel on a continuous fixed-bed reactor. J. Catal. 2006, 242, 299-308. [CrossRef]

88. Wan Abu Bakar, W.; Rusmidah Ali, R.; Abdul Kadir, A.; Wan Mokhtar, W. Effect of transition metal oxides catalysts on oxidative desulfurization of model diesel. Fuel Process. Technol. 2012, 101, 78-84. [CrossRef]

89. Sundararaman, S.; Song, C. Catalytic Oxidative Desulfurization of Diesel Fuels Using Air in a Two-Step Approach. Ind. Eng. Chem. Res. 2014, 53, 1890-1899. [CrossRef]

90. Cheng, S.S. Ultra Clean Fuels via Modified UAOD Process with Room Temperature Ionic Liquid (RTIL) \& Solid Catalyst Polishing. Ph.D. Thesis, University of Southern California, Los Angeles, CA, USA, 2008. Available online: http:/ / cee.usc.edu/assets/025/85741.pdf (accessed on 20 October 2016).

91. Alavi, S.A.; Hashemi, S.H. A Review on Diesel Fuel Desulfurization by Adsorption Process. In Proceedings of the International Conference on Chemical, Agricultural, and Biological Sciences, Antalya, Turkey, 2-3 May 2014; pp. 33-36. 
92. Velu, S.; Watanabe, S.; Ma, X.; Song, C. Reganarable adsorbents for the adsorptive desulphurization of transportation fuels for fuel cell applications. Chem. Soc. Div. Fuel Chem. 2003, 48, 482-526.

93. Zhanga, Y.; Yang, Y.; Han, H.; Yang, M.; Wang, L.; Zhang, Y.; Jiang, Z.; Li, C. Ultra-deep desulfurization via reactive adsorption on $\mathrm{Ni} / \mathrm{ZnO}$ : The effect of $\mathrm{ZnO}$ particle size on the adsorption performance. Appl. Catal. B Environ. 2012, 119, 13-19. [CrossRef]

94. Gislason, J. Phillips Sulfur removal process nears commercialization. Oil Gas J. 2002, 99, 74-76.

95. Ma, X.; Velu, S.; Kim, J.H.; Song, C. Deep desulfurization of gasoline by selective adsorption over solid adsorbents and impact of analytical methods on ppm-level sulfur quantification for fuel cell applications. Appl. Catal. B Environ. 2005, 56, 137-147. [CrossRef]

96. Tawfik, A.; Saleh, G.I.; Danmaliki, T.D.S. Nanocomposites and Hybrid Materials for Adsorptive Desulfurization. Advances in Chemical and Materials Engineering (ACME); IGI Global: Hershey, PA, USA, 2015; pp. 129-153.

97. Ryzhikov, A.; Bezverkhyy, I.; Bellat, J.P. Reactive adsorption of thiophene on Ni/ZnO: Role of hydrogen pretreatment and nature of the rate determining step. Appl. Catal. B 2008, 84, 766-772. [CrossRef]

98. Tawara, K.; Nishimura, T.; Iwanami, H.; Nishimoto, T.; Hasuike, T. New hydrodesulfurization catalyst for petroleum-fed fuel cell vehicles and cogenerations. Ind. Eng. Chem. Res. 2001, 40, 2367-2370. [CrossRef]

99. Srivastav, A.; Srivastava, V.C. Adsorptive desulfurization by activated alumina. J. Hazard. Mater. 2009, 170, 1133-1140. [CrossRef] [PubMed]

100. Tawara, K.; Nishimura, T.; Iwanami, H.; Shi, S.G. Ultra-deep hydrodesulfurization of kerosene for fuel cell system. Part 2: Regeneration of sulfur-poisoned nickel catalyst in hydrogen and finding of autoregenerative nickel catalyst. J. Jpn. Petrol. Inst. 2000, 43, 114-120. [CrossRef]

101. Kim, J.H.; Ma, X.; Zhou, A.; Song, C. Ultra-deep desulfurization and denitrogenation of diesel fuel by selective adsorption over three different adsorbents: A study on adsorptive selectivity and mechanism. Catal. Today 2006, 111, 74-83. [CrossRef]

102. Bezverkhyy, I.; Ryzhikov, A.; Gadacz, G.; Bellat, J.P. Kinetics of thiophene reactive adsorption on $\mathrm{Ni} / \mathrm{SiO}{ }_{2}$ and Ni/ZnO. Catal. Today 2008, 130, 199-205. [CrossRef]

103. Gawande, P.R.; Dr., Jayant, P.K. A Review on Desulphurization of Liquid Fuel by Adsorption. Int. J. Sci. Res. 2014, 3, 2255-2259.

104. Moosavi, E.S.; Seyed, A.; Dastgheib, A.S.; Karimzadeh, R. Article Adsorption of Thiophenic Compounds from Model Diesel Fuel Using Copper and Nickel Impregnated Activated Carbons. Energies 2012, 5, 4233-4250. [CrossRef]

105. Yang, R.T.; Hernandez-Maldonado, A.J.; Yang, F.H. Desulfurization of transportation fuels with Zeolites under ambient conditions. Science 2003, 301, 79-81. [CrossRef] [PubMed]

106. Liu, B.; Peng, Y.; Chen, Q. Adsorption of N/S-Heteroaromatic Compounds from Fuels by Functionalized MIL-101(Cr) Metal-Organic Frameworks: The Impact of Surface Functional Groups. Energy Fuels 2016, 30, 5593-5600. [CrossRef]

107. "Incorporating Biotechnology into the Classroom What is Biotechnology?" from the Curricula of the "Incorporating Biotechnology into the High School Classroom through Arizona State University's BioREACH Program". Available online: http://www.public.asu.edu/ langland/biotech-intro.html (accessed on 5 November 2016).

108. Singh, A.; Singh, B.; Ward, O. Potential applications of bioprocess technology in petroleum industry. Biodegradation 2012, 23, 865-880. [CrossRef] [PubMed]

109. Gavrilescu, M.; Chisti, Y. Biotechnology a sustainable alternative to chemical industry. Biotechnol. Adv. 2005, 23, 471-499. [CrossRef] [PubMed]

110. Singh, B.K. Exploring microbial diversity for biotechnology: The way forward. Trends Biotechnol. 2010, 28, 111-116. [CrossRef] [PubMed]

111. Huang, X.-F.; Guan, W.; Liu, J.; Lu, L.-J.; Xu, J.-C.; Zhou, Q. Characterization and phylogenetic analysis of biodemulsifier-producing bacteria. Bioresour. Technol. 2010, 101, 317-323. [CrossRef] [PubMed]

112. Ward, O.P.; Singh, A.; Van Hamme, J.D.; Voordouw, G. Petroleum microbiology. In Encyclopedia of Microbiology, 3rd ed.; Schaechter, M., Ed.; Elsevier: Amsterdam, The Netherlands, 2009; pp. 443-456.

113. Voordouw, G. Production-related petroleum microbiology: Progress and prospects. Curr. Opin. Biotechnol. 2011, 22, 401-405. [CrossRef] [PubMed] 
114. Alves, L.; Silva, T.P.; Arez, B.F.; Paixão, S.M. Enhancement of dibenzothiophene biodesulfurization by Gordonia alkanivorans strain 1B using fructose rich culture media. In Proceedings of the 1st International Congress on Bioenergy, Book of Abstracts, Portalegre, Portugal, 23-25 May 2013; p. 48.

115. Alves, L.; Salgueiro, R.; Rodrigues, C.; Mesquita, E.; Matos, J.; Girio, F.M. Desulfurization of dibenzothiophene, benzothiophene, and other thiophene analogs by a newly isolated bacterium, Gordonia alkanivorans strain 1B. Appl. Biochem. Biotechnol. 2005, 120, 199-208. [CrossRef]

116. Pacheco, M.A.; Lange, E.A.; Pienkos, P.T.; Yu, L.Q.; Rouse, M.P.; Lin, Q.; Linguist, L.K. Recent advances in biodesulfurization of diesel fuel. In Proceedings of the 1999 National Petrochemical and Refiners Association, Annual Meeting, NPRA AM-99-27, San Antonio, TX, USA, 21-23 March 1999; pp. 1-26.

117. Linguist, L.K.; Pacheco, M.A. Enzyme-based diesel desulfurization process offers energy, $\mathrm{CO}_{2}$ advantages. Oil Gas J. 1999, 97, 45-48.

118. Kaufman, E.N.; Harkins, J.B.; Borole, A.P. Comparison of batchstirred and electrospray reactors for biodesulfurization of dibenzothiophene in crude oil and hydrocarbon feedstocks. Appl. Biochem. Biotechnol. 1998, 73, 127-144. [CrossRef]

119. Abín-Fuentes, A. Mechanistic Understanding of Microbial Desulfurization. Ph.D. Thesis, Massachusetts Institute of Technology, Department of Chemical Engineering, Cambridge, MA, USA, 2013.

120. Konishi, J.; Ishii, Y.; Onaka, T. Thermophilic carbon-sulfur-bond-targeted biodesulfurization. Appl. Environ. Microbiol. 1997, 63, 3164-3169. [PubMed]

121. Borgne, S.L.; Quintero, R. Biotechnological processes for the refining of petroleum. Fuel Process. Technol. 2003, 81, 155-169. [CrossRef]

122. Soleimani, M.; Bassi, A.; Margaritis, A. Biodesulfurization of refractory organic sulphur compounds in fossil fuels. Biotechnol. Adv. 2007, 25, 570-596. [CrossRef] [PubMed]

123. Madeira, L.; Santana, V.; Pinto, E. Dibenzothiophene oxidation by horseradish peroxidase in organic media: Effect of the DBT: $\mathrm{H}_{2} \mathrm{O}_{2}$ molar ratio and $\mathrm{H}_{2} \mathrm{O}_{2}$ addition mode. Chemosphere 2008, 71, 189-194. [CrossRef] [PubMed]

124. Mohebali, G.; Ball, A.S.; Rasekh, B.; Kaytash, A. Biodesulphurization potential of a newly isolated bacterium, Gordonia alkanivorans RIPI90A. Enzym. Microb. Technol. 2007, 40, 578-584. [CrossRef]

125. Alves, L.; Marque, S.; Matos, J.; Tenreiro, R.; Gírio, F.M. Dibenzothiophene Desulfurization by Gordonia alkanivorans Strain 1B Using Recycled Paper Sludge Hydrolyzate. Chemosphere 2008, 70, 967-973. [CrossRef] [PubMed]

126. Caro, A.; Leton, P.; Calvo, E.G.; Setti, L. Enhancement of dibenzothiphene biodesulphurization using $\beta$-cyclodextrins in oil-to-water media. Fuel 2007, 86, 2632-2636. [CrossRef]

127. Chen, H.; Zhang, H.W.J.; Chen, J.M.; Cai, Y.B.; Li, W. Desulfurization of various organic sulphur compounds and the mixture of DBT + 4,6-DMDBT by Mycobacterium sp. ZD-19. Bioresour. Technol. 2008, 99, 6928-6933. [CrossRef] [PubMed]

128. Li, F.; Zhang, Z.; Feng, J.; Cai, X.; Ping, X. Biodesulfurization of DBT in tetradecane and crude oil by a facultative thermophilic bacterium Mycobacterium goodii X7B. J. Biotechnol. 2007, 127, 222-228. [CrossRef] [PubMed]

129. Ayala, M.; Tinoco, R.; Hernandez, V.; Bremauntz, P.; Duhalt, R.V. Biocatalytic oxidation of fuel as an alternative to biodesulfurization. Fuel Process. Technol. 1998, 57, 101-111. [CrossRef]

130. Kirimura, K.; Furuya, T.; Nishii, Y.; Ishii, Y.; Kino, K.; Usami, S. Biodesulfurization of dibenzothiophene and its derivatives through the selective cleavage of carbon-sulphur bonds by a moderately thermophilic bacterium Bacillus subtilis WU-S2B. J. Biosci. Bioeng. 2001, 91, 262-266. [CrossRef]

131. Furuya, T.; Kirimura, K.; Kino, K.; Usami, S. Thermophilic biodesulfurization of dibenzothiophene and its derivatives by Mycobacterium phlei WU-F1. FEMS Microbiol. Lett. 2001, 204, 129-133. [CrossRef] [PubMed]

132. Maghsoudi, S.; Vossoughi, M.; Kheirolomoom, A.; Tanaka, E.; Katoh, S. Biodesulfurization of hydrocarbons and diesel fuels by Rhodococcus sp. strain P32C1. Biochem. Eng. J. 2001, 8, 151-156. [CrossRef]

133. Oda, S.; Ohta, H. Biodesulfurization of dibenzothiophene with Rhodococcus erythropolis ATCC 53968 and its mutant in an interface bioreactor. J. Biosci. Bioeng. 2002, 94, 474-477. [CrossRef]

134. Li, F.L.; Xu, P.; Ma, C.Q.; Luo, L.L.; Wang, X.S. Deep desulfurization of hydrodesulfurization-treated diesel oil by a facultative thermophilic bacterium Mycobacterium sp. X7B. FEMS Microbiol. Lett. 2003, 223, 301-307. [CrossRef] 
135. Li, W.; Zhang, Y.; Wang, M.D.; Shi, Y. Biodesulfurization of dibenzothiophene and other organic sulphur compounds by a newly isolated Microbacterium strain ZD-M2. FEMS Microbiol. Lett. 2005, 247, 45-50. [CrossRef] [PubMed]

136. Hou, Y.; Kong, Y.; Yang, J.; Zhang, J.; Shi, D.; Xin, W. Biodesulfurization of dibenzothiophene by immobilized cells of Pseudomonas stutzeri UP-1. Fuel 2005, 84, 1975-1979. [CrossRef]

137. Gunam, I.B.W.; Yaku, Y.; Hirano, M.; Yamamura, K.; Tomita, F.; Sone, T.; Asano, K. Biodesulfurization of Alkylated Forms of Dibenzothiophene and Benzothiophene by Sphingomonas subarctica T7b. J. Biosci. Bioeng. 2006, 101, 322-327. [CrossRef] [PubMed]

138. Rashtchi, M.; Mohebali, G.H.; Akbarnejad, M.M.; Towfighi, J.; Rasekh, B.; Keytash, A. Analysis of Biodesulphurization of model oil system by the bacterium strain RIPI-22. Biochem. Eng. J. 2006, 29, 169-173. [CrossRef]

139. Guobin, S.; Huaiying, Z.; Jianmin, X.; Guo, C.; Wangliang, L.; Huizhou, L. Biodesulfurization of hydrodesulfurized diesel oil with Pseudomonas delafieldii R-8 from high density culture. Biochem. Eng. J. 2006, 27, 305-309. [CrossRef]

140. Grossman, M.J.; Siskin, M.; Ferrughelli, D.T.; Lee, M.K.; Senius, J.D. Method for the Removal of Organic Sulfur from Carbonaceous Materials. U.S. Patent 5910440, 8 June 1999.

141. Konishi, J.; Ishi, Y.; Okumura, K.; Suzuki, M. High Temperature Desulfurization by Microorganisms. U.S. Patent 5,925,560, 20 July 1999.

142. Kim, T.S.; Kim, H.Y.; Kim, B.H. Petroleum Desulfurization by DesulfovibrioDesulfuricans M6 using electrochemically supplied reducing equivalent. Biotechnol. Lett. 1990, 12, 757-760. [CrossRef]

143. Borole, A.P.; Kaufman, E.N.; Grossman, M.J.; Minak-Bernero, V.; Bare, R.; Lee, M.K. Comparison of the emulsion characteristics of Rhodococcus erythropolis and Ecsherichia coli SOXC-5 cells expressing biodesulfurization genes. Biotechnol. Prog. 2002, 18, 88-93. [CrossRef] [PubMed]

144. Nehlsen, J.P. Developing Clean Fuels: Novel Techniques for Desulfurization. Ph.D. Thesis, Princeton University, Princeton, NJ, USA, 2005.

145. Matsui, T.; Onaka, T.; Maruhashi, K.; Kurane, R. Benzothiophene desulfurization by Gordonia rubropertinctus strain T08. Appl. Microbiol. Biotechnol. 2001, 57, 212-215. [PubMed]

146. Gün, G.; Yürüm, Y.; Doğanay, G.D. Revisiting the biodesulfurization capability of hyperthermophilic archaeon Sulfolobus solfataricus P2 revealed DBT consumption by the organism in an oil/water two-phase liquid system at high temperatures. Turk. J. Chem. 2015, 39, 255-266. [CrossRef]

147. Monticello, D.J. Biodesulfurization and the upgrading of petroleum distillates. Curr. Opin. Biotechnol. 2000, 11, 540-546. [CrossRef]

148. Yu, B.; Ma, C.; Zhou, W.; Zhu, S.; Wang, Y.; Qu, J.; Li, F.; Xu, P. Simultaneous Biodetoxification of S, N, and O Pollutants by Engineering of a Carbazole-Degrading Gene Cassette in a Recombinant Biocatalyst. Appl. Environ. Microbiol. 2006, 72, 7373-7376. [CrossRef] [PubMed]

149. Mohebali, G.; Ball, A.S. Biocatalytic desulfurization (BDS) of petrodiesel fuels. Microbiology 2008, 154, 2169-2183. [CrossRef] [PubMed]

150. Kertesz, M.A.; Wirtek, C. Desulfurization and desulfonation: Application of sulphur-controlled gene expression in bacteria. Appl. Microbiol. Biotechnol. 2001, 57, 460-466. [PubMed]

151. Berthou, F.; Gourmelun, Y.; Dreano, Y.; Friocourt, M.P. Application of gas chromatography on glass capillary columns to the analysis of hydrocarbon pollutants from the Amoco Cadiz oil spill. J. Chromatogr. 1981, 203, 279-292. [CrossRef]

152. Yu, B.; Xu, P.; Shi, Q.; Ma, C. Deep desulfurization of diesel oil and crude oils by a newly isolated Rhodococcus erythropolis strain. Appl. Environ. Microbiol. 2006, 72, 54-58. [CrossRef] [PubMed]

153. Bhatia, S.; Sharma, D.K. Thermophilic desulfurization of dibenzothiophene and different petroleum oils by Klebsiella sp. 13T. Environ. Sci. Pollut. Res. Int. 2012, 19, 3491-3497. [CrossRef] [PubMed]

154. Chen, H.; Cai, Y.B.; Zhang, W.J.; Li, W. Methoxylation pathway in biodesulfurization of model organosulfur compounds with Mycobacterium sp. Bioresour. Technol. 2009, 100, 2085-2087. [CrossRef] [PubMed]

155. Pokethitiyooka, P.; Tangaromsuk, J.; Kruatrachue, M.; Kalambaheti, C.; Borole, A.P. Biological removal of organic sulphur by bacterial strains isolated in Thailand. Sci. Asia 2008, 34, 361-366. [CrossRef]

156. Yamada, K.O.; Morimoto, M.; Tani, Y. Degradation of dibenzothiophene by sulfate-reducing bacteria cultured in the presence of onlynitrogen gas. J. Biosci. Bioeng. 2001, 91, 91-93. [CrossRef] 
157. Armstrong, S.M.; Sankey, B.; Voordouw, G. Conversion of diben-zothiophene to biphenyl by sulfate reducing bacteria isolated fromoil field production facilities. Biotechnol. Lett. 1995, 17, 1133-1136. [CrossRef]

158. Kirkwood, K.M.; Ebert, S.; Foght, J.M.; Fedorak, P.M.; Gray, M.R. Bacterial biodegradation of aliphatic sulfides under aerobic carbon- or sulfur-limited growth conditions. J. Appl. Microbiol. 2005, 99, 1444-1454. [CrossRef] [PubMed]

159. Kirkwood, K.M.; Andersson, J.T.; Fedorak, P.M.; Foght, J.M.; Gray, M.R. Sulfur from benzothiophene and alkylbenzothiophenes supports growth of Rhodococcus sp. strain JVH1. Biodegradation 2007, 18, 541-549. [CrossRef] [PubMed]

160. Kirkwood, K.M.; Foght, J.M.; Gray, M.R. Selectivity among organic sulphur compounds in one-and two-liquid-phase cultures of Rhodococcus sp. strain JVH1. Biodegradation 2007, 18, 473-480. [CrossRef] [PubMed]

161. Rhee, S.K.; Chang, J.H.; Chang, Y.K.; Chang, H.N. Desulfurization of dibenzothiophene and diesel oils by a newly isolated Gordona strain, CYKS1. Appl. Environ. Microbiol. 1998, 64, 2327-2331. [PubMed]

162. Chang, J.H.; Chang, Y.K.; Cho, K.S.; Chang, H.N. Desulfurization of model and diesel oils by resting cells of Gordona sp. Biotechnol. Lett. 2000, 22, 193-196. [CrossRef]

163. Chang, J.H.; Kim, Y.J.; Lee, B.H.; Cho, K.S.; Rye, H.W.; Chang, Y.K.; Chang, H.N. Production of a desulfurization biocatalyst by two-stage fermentation and its application for the treatment of model and diesel oils. Biotechnol. Prog. 2001, 17, 876-880. [CrossRef] [PubMed]

164. Grossman, M.J.; Lee, M.K.; Prince, R.C.; Minak-Bernero, V.; George, G.N.; Pickering, I.J. Deep desulfurization of extensively hydrodesulfurized middle distillate oil by Rhodococcus sp. strain ECRD-1. Appl. Environ. Microbiol. 2001, 67, 1949-1952. [CrossRef] [PubMed]

165. Folsom, B.R.; Schieche, D.R.; DiGrazia, P.M.; Werner, J.; Palmer, S. Microbial desulfurization of alkylated dibenzothiophenes from a hydrodesulfurized middle distillate by Rhodococcus erythropolis I-19. Appl. Environ. Microbiol. 1999, 65, 4967-4972. [PubMed]

166. Ishii, Y.; Kozaki, S.; Furuya, T.; Kino, K.; Kirimura, K. Thermophilic biodesulfurization of various heterocyclic sulphur compounds and crude straight-run light gas oil fraction by a newly isolated strain Mycobacterium phlei WU-0103. Curr. Microbiol. 2005, 50, 63-70. [CrossRef] [PubMed]

167. Guobin, S.; Jianmin, X.; Huaiying, Z.; Huizhou, L. Deep desulfurization of hydrodesulfurized diesel oil by Pseudomonas delafieldii R-8. J. Chem. Technol. Biotechnol. 2005, 80, 420-424. [CrossRef]

168. Kobayashi, M.; Onaka, T.; Ishii, Y.; Konishi, J.; Takaki, M.; Okada, H.; Ohta, Y.; Koizumi, K.; Suzuki, M. Desulfurization of alkylated forms of both dibenzothiophene and benzothiophene by a single bacterial strain. FEMS Microbiol. Lett. 2000, 187, 123-126. [CrossRef] [PubMed]

169. Ohshiro, T.; Hirata, T.; Izumi, Y. Desulfurization of dibenzothiophene derivatives by whole cells of Rhodococcus erythropolis H-2. FEMS Microbiol. Lett. 1996, 142, 65-70. [CrossRef]

170. Rashidi, L.; Mohebali, G.; Towfighi darian, J.; Rasekh, B. Biodesulfurization of dibenzothiophene and its alkylated derivatives through the sulphur-specific pathway by the bacterium RIPI-S81. Afr. J. Biotechnol. 2006, 5, 351-356.

171. Okada, H.; Nomura, N.; Nakahara, T.; Maruhaski, K. Analysis of dibenzothiophene metabolic pathway in Mycobacterium sp. G3. J. Biosci. Bioeng. 2002, 93, 491-497. [CrossRef]

172. Lee, M.K.; Senius, J.D.; Grossman, M.J. Sulfur-specific microbial desulfurization of sterically hindered analogs of dibenzothiophene. Appl. Environ. Microbiol. 1995, 61, 4362-4366. [PubMed]

173. Paixão, S.M.; Silva, T.P.; Arez, B.F.; Alves, K. Advances in the Reduction of the Costs Inherent to Fossil Fuels Biodesulfurization towards its Potential Industrial Application. In Applying Nanotechnology to the Desulfurization Process in Petroleum Engineering; IGI Global: Hershey, PA, USA, 2016; Chapter 13; pp. 390-425.

174. Rosenberg, M.; Gutnick, D.; Rosenberg, E. Adherence of bacteria to hydrocarbons: A simple method for measuring cell-surface hydrophobicity. FEMS Microbiol. Lett. 1980, 9, 29-33. [CrossRef]

175. Alves, L.; Paixão, S.M. Enhancement of Dibenzothiophene Desulfurization by Gordonia alkanivorans Strain 1B Using Sugar Beet Molasses as Alternative Carbon Source. Appl. Biochem. Biotechnol. 2014, 31, 73-79. [CrossRef] [PubMed]

176. Setti, L.; Lanzarini, G.; Pifferi, P.G. Immobilized cells for applications in non-conventional systems. In Progress in Biotechnology. Immobilized Cells: Basics and Applications; Wijffels, R.H., Buitelaar, R.M., Bucke, C., Tramper, J., Eds.; Elsevier: Amsterdam, The Netherlands, 1996; Volume 11, pp. 777-784.

177. Guobin, S.; Huaiying, Z.; Weiquan, C.; Jianmin, X.; Huizhou, L. Improvement of Biodesulfurization Rate by Assembling Nanosorbents on the Surfaces of Microbial Cells. Biophys. J. 2005, 89, L58-L60. [CrossRef] [PubMed]

(C) 2017 by the authors. Licensee MDPI, Basel, Switzerland. This article is an open access article distributed under the terms and conditions of the Creative Commons Attribution (CC BY) license (http:/ / creativecommons.org/licenses/by/4.0/). 